DOI: 10.17951/rh.2017.44.193-215

Ludmiła Mazur

(Ural Federal University, Ekaterinburg, Russia)

\title{
Images of Power in the Early Soviet Society: Evolution of Official Representations, Sources and Mechanisms of Their Construction
}

\author{
Wizerunki władzy w społeczeństwie wczesnoradzieckim: \\ Ewolucja oficjalnych obrazów, źródet i mechanizmów ich tworzenia
}

\begin{abstract}
The article discusses creation and evolution of the official image of Soviet state power between 1917 and the 1930s. This image was deliberately constructed and included symbols of statehood (national coat of arms; motto; flag; and anthem); institutions that embodied characteristics of power organization; leaders as personification of power; the state myth; rituals; and sites of memory. Throughout the early Soviet period, the evolving image of power reflected the changes in the government's self-understanding. Regarding the structure and the ideological content of the image of power, we can point out three successive variations: revolutionary, people's (workers and peasants), and Party-state. The article describes the structure of these variations and the factors that shaped their development.
\end{abstract} viet power

Key words: symbols of power, Soviet government, early Soviet society, image of So-

Displays of power are an important aspect of government strategies and practices, which determine the perception of the government both by the public and by the international community. Through the public image of power, the government conveys information about its mission, goals, and means of achieving them. As a result of the revolutions and civil wars, the Russian society was deeply divided, which led to the creation of a new state. One of the crucial tasks faced by the Soviet regime was to create a new image of power and to legitimize itself in the conditions of social turmoil. The Soviet government not only sought to "conquer" the country and establish control over it, but to create a sustainable social base for further development. 
The image of power was primarily formed through government practices, which had to be supported by the society. To gain people's approval, the government used agitation and propaganda to convince the public of the necessity and practical value of the proposed measures. In case of open confrontation, the government resorted to force (coercion, intimidation, persecutions). As history shows, the persuasive power of fear serves as a good supplement to slogans and other means of agitation. In the long term, the government ensured people's loyalty and support through such mechanism as upbringing - the system of rules and norms approved by the government which influence people's minds and behaviour through state rituals and holidays, sites of memory, mass media, education, literature, art, and science. In Soviet practice, the function of upbringing was realized not only by the Party and state structures but also by public organizations, production structures, including the penal system (Gulag), which followed the formula of "correction through labour".

Thus, the image of Soviet power was deliberately constructed through various mechanisms and by employing various resources. Yet, we should not limit ourselves only to the reconstruction and analysis of official representations of power. The image that was constructed and disseminated by the government was perceived by the public in a variety of ways, ranging from "positive" perceptions, which corresponded to the government's intention, to "critical" and "negative", which reflected the protest moods in the society. Therefore, we should focus on the reconstruction and analysis of these types of public perception of power: how they were represented in the mass consciousness and how they affected collective reactions.

This article aims to identify the key symbols and to reconstruct the official image of Soviet state power by tracing back its evolution in the early Soviet period (1917-1930s).

The significant characteristic of this period is social experimentation: the Bolsheviks found themselves at the helm of the country ravaged by the war, still feverish after the Revolution, therefore, they had to tackle a range of problems, starting from formation of the new state, its protection and consolidation in the wake of the civil war to social transformations and building a Communist society.

These two goals - protection of the "Socialist motherland" and building of Communism - shaped the long-term ideological agenda of the Soviet government, especially in the early Soviet period. These goals set the main trend in how power was displayed as the government not only needed to win over people's loyalty but also gain their active support, which meant that people had to be willing to cooperate and even risk their lives for the new regime. Therefore, formation of the public image of power was accompanied by in- 
tensive social engineering, which was aimed at the creation of the New Person - an "ardent activist" and "staunch communist", in other words, a person who does not question the Party's and government's orders.

It should be noted that in constructing its public image, the Soviet government originally intended to reject the old political tradition (monarchy) and to position the new government bodies (Soviets) as the mouthpiece for the exploited classes. The idea of "people's power"1 was then replaced by the idea of klassovost (class consciousness), which had a direct impact on the ways the new regime chose to represent its social base.

Looking at how the image of Soviet power evolved, it is important to take into account the "political baggage" which the Bolsheviks had accumulated by the time of the October coup. As representatives of the radical underground political culture, which sought to break away from the old order, the Bolsheviks started to implement these principles in their state policy when they came to power. Their policy was aimed at eliminating the opposition and, thus, achieving unity that would have excluded dissidence.

The Bolsheviks lacked the skills of conducting political dialogue and experience of parliamentary government, they also rejected the liberal model of power as bourgeois heritage. Therefore, they laid the ideas of struggle and unity at the core of the image of Soviet power. Another key component of this image was the future which required all kinds of sacrifices and justified whatever decisions the government made (see Table 1). Thus, the message based on this complex of ideas (future, struggle, unity, and klassovost) was at the heart of the image of Soviet power and was conveyed through structural symbols and signs.

\section{STRUCTURE OF THE IMAGE OF POWER}

The image of power is a semiotic system that comprises the government's representation of itself and representations of power that emerge within society. These include ideas about the nature of power, its functions and structure and people's social and political expectations ${ }^{2}$. The image of power should be clear and easy to perceive and show the difference

1 Here I am referring to the "theory of official nationality" proposed by S.S. Uvarov. For more detail, see: R. Vortman, Offitsialnaya narodnost' $i$ natsionalny mif rossiyskoy monarkhii XIX veka, in: ROSSIA/RUSSIA, 3 (11): Kulturnye praktiki $v$ ideologicheskoy perspective, Moskva 1999, pp. 233-244.

2 N.A. Romanovich, Obraz vlasti kak otrazhenie rossiyskoy politicheskoy kultury, "Vestnik Voronezhskogo gosudarstvennogo universiteta, Seria: lingvistika i mezhkulturnaya kommunikatsia" 2010, 1, p. 169. 
between this regime and others, previous or alternative. Furthermore, the system of power has to include ideas and symbols reflecting the general attributes of power and symbolizing its might and strength, progress (crucial for the modernization period), stability, justice, and narodnost or national character (the government as the spokesman for the people and protector of their interests).

The following elements constituted the image of power and determined its effectiveness as an instrument of influence:

- symbols reflecting the state mission (coat of arms, motto, flag, anthem, and the signs of the star, sickle and hammer),

- state institutions embodying organizational and legal foundations of power (Soviets, Red Army, Bolshevik Party, and so on),

- social groups which the government relies on and which are considered as its adherents (working class, peasantry),

- personifications of power in a specific historical and territorial aspect (leaders),

- state myth (Soviet myth),

- rituals (state ceremonies and holidays),

- sites of memory (monuments, memorials, museums, and documents such as a constitution, declaration, manifest, and banknotes).

Power is primarily displayed through state symbols. According to B.I. Kolonitsky, "symbols make an integral part of formation, formalization, and reproduction of identity of any political structure or group" ${ }^{\prime 3}$. Symbols not only legitimize the governing regime but also foster loyalty among its faithful supporters. They also play a compensatory role as they relieve social anxieties and tensions, shifting the focus of people's attention from their current problems to more global aims. Yet one more function that should be mentioned is communication: symbols communicate the main ideas of the government to people and inscribe them on the subconscious level, thus, turning these symbols into channels of information. The national coat of arms represents the quintessence of national identity and statehood: all its elements, starting from the general design to the most minute details, are imbued with meaning (Fig. 1).

The image must be complete: a lack of certain elements or inadequate combination of elements can affect its efficiency. Creation of a proper image of power is a time-consuming process, which comprises such stages as designing, construction, and reconstruction. How much time and effort are invested in this process largely depends on the government's position

3 B.I. Kolonitsky, Simvoly vlasti i borba za vlast: $k$ izucheniyu politicheskoy kultury rossiyskoy revolutsii 1917 g., St. Petersburg 2000. 


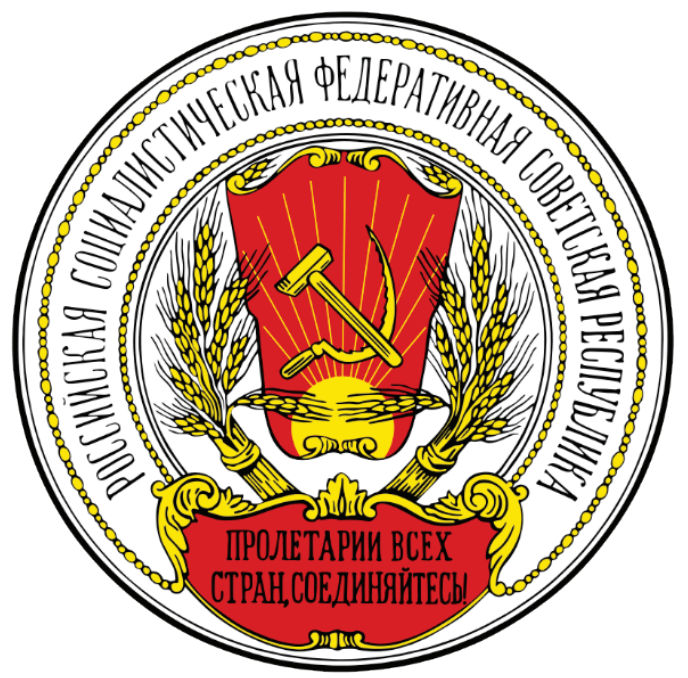

Fig. 1. National coat of arms of the RSFSR (19 July 1918-20 July 1920)

(whether it upholds the continuity of tradition or rejects the heritage of the previous regimes); internal and external conditions (stable/unstable); availability of image production mechanisms and the government's mastery of these mechanisms as well as the government's awareness of the importance of these tasks.

The construction of the image of Soviet power comprised two distinct stages: the period of spontaneous construction (November 1917-March 1918): the process of construction was chaotic, based on intuitive reasoning and on the Party's underground experience of interaction with the masses. At this stage, the image of power was primarily constructed through the legislative practices of the new governmental bodies. One of the key roles was played by decrees, which signified the Bolsheviks' determination to realize their promises made in the period of the October coup and to meet the expectations of the masses (peasants, workers, and soldiers).

Starting from April 1918, when the main propaganda structures were created, the process of image construction became more and more organized, focused, and directed by the government, which monopolized control over the mass media, education, literature, art, cinema, and other information channels and used them for its own ends.

Thus, the image of power operates with emotionally charged symbols, it is dynamic and can be transformed in response to the current agenda. At its core, however, the image of power is stable and provides historical, temporal and spatial identity of statehood. The efficiency of the constructed 
image of power can be estimated through its public perceptions: the more identical they are, the more efficient the image of power is, although in reality full unanimity is rarely found. Even in totalitarian societies in which conformity is enforced, there is an opposition seeking to present its own, alternative image of power.

\section{EVOLUTION OF THE IMAGE OF SOVIET POWER}

In its evolution, the image of power is influenced by a number of factors, which can be divided into subjective and objective. Subjective factors are determined by internal and external conditions in which the regime operates. For example, war is a destabilizing factor, capable of destroying the attractive image of power. The same can be said about the results of foreign and domestic policy and the level of public trust. Subjective factors are directly related to historical figures that exercise authority. The image of power tends to be personified and associated with specific political leaders, their personal image and level of popularity.

Although the image of power kept changing throughout the early Soviet history (1917-1930s), it also retained certain features which allow us to characterize it as an image of Soviet power. The variations of this image, however, are quite different in their structure and in the tasks they sought to address. We can identify three successive images of Soviet state power that corresponded to the periods of the early Soviet society: revolutionary; workers and peasants' (people's power); and Party-state. Each of these images reflected changes in the ideological and political agenda (see Table 1).

In the revolutionary image of Soviet power, symbols of the 1917 Revolution prevailed: for example, the red flag, revolutionary songs, and the sickle and the hammer. The Bolsheviks adjusted these symbols for the Soviet model, which shows that there was a connection between the bourgeoisdemocratic and proletarian stages of the Revolution that the Bolsheviks spoke so much about.

Under the Soviet regime, the red flag became a state symbol, thus, not only reflecting such meanings of the February Revolution as freedom and sacrifice but also the idea of relentless struggle against the past and its representatives for the sake of the bright Communist future. Thus, the practices of the Soviet government were to some extent similar to those of the Provisional Government, which, after the old state coat of arms had been abolished, immediately sought to replace it with a new one. The sickle and hammer emblem was used on the flag of one of the Russian army regiments as early as in the spring of 1917. D.O. Khelaev, a Socialist-Revolutionary, suggested the image of the 
Table 1. Structure of the image of Soviet power and its evolution in 1917-1930s

\begin{tabular}{|c|c|c|c|}
\hline $\begin{array}{c}\text { Image } \\
\text { structure }\end{array}$ & $\begin{array}{l}\text { Revolutionary image } \\
\text { (1917-1923) }\end{array}$ & $\begin{array}{c}\begin{array}{c}\text { Workers and peasants' } \\
\text { (people's power) image } \\
(1924-1929)\end{array} \\
\end{array}$ & $\begin{array}{l}\text { Party-state image } \\
\text { (1930s) }\end{array}$ \\
\hline Ideas & $\begin{array}{l}\text { Future }+ \text { struggle + } \\
\text { klassovost }\end{array}$ & $\begin{array}{l}\text { Future + struggle + } \\
\text { unity }+ \text { klassovost }\end{array}$ & $\begin{array}{l}\text { Unity + klassovost + } \\
\text { struggle + future }\end{array}$ \\
\hline $\begin{array}{l}\text { State symbols; } \\
\text { signs }\end{array}$ & $\begin{array}{l}\text { Revolutionary sym- } \\
\text { bols and signs: red } \\
\text { flag, coat of arms, } \\
\text { anthem (International); } \\
\text { sickle and hammer, } \\
\text { star }\end{array}$ & $\begin{array}{l}\text { Revolutionary symbols } \\
+ \text { symbols of peaceful } \\
\text { labour and internation- } \\
\text { al brotherhood. Codifi- } \\
\text { cation of state symbols } \\
\text { of the Soviet republics } \\
\text { and the USSR }\end{array}$ & $\begin{array}{l}\text { Continuity of state } \\
\text { symbols of the repub- } \\
\text { lics and the USSR: } \\
\text { signs of strength/ } \\
\text { might (machines, } \\
\text { factories, power sta- } \\
\text { tions, tractors, plans, } \\
\text { and so on); signs of } \\
\text { prosperity and happi- } \\
\text { ness (bread, children, } \\
\text { flowers) }\end{array}$ \\
\hline Institutions & Soviets, Red Army & $\begin{array}{l}\text { Soviets, Red Army, } \\
\text { Bolshevik Party, public } \\
\text { organizations (trade } \\
\text { unions, women's coun- } \\
\text { cils, Komsomol (Youth } \\
\text { Communist League), } \\
\text { DOSAAF (Russian } \\
\text { Army, Air Force and } \\
\text { Navy Volunteer Soci- } \\
\text { ety), etc.) }\end{array}$ & $\begin{array}{l}\text { KPSS (Communist } \\
\text { Party of the Soviet } \\
\text { Union), Red Army, } \\
\text { Supreme Soviet }\end{array}$ \\
\hline $\begin{array}{l}\text { Society/social } \\
\text { groups }\end{array}$ & $\begin{array}{l}\text { Society split into two } \\
\text { camps: revolutionary } \\
\text { (workers, peasants) } \\
\text { and counterrevolu- } \\
\text { tionary (bourgeoisie, } \\
\text { public officials, offic- } \\
\text { ers, meschane, kulaks, } \\
\text { the clergy) }\end{array}$ & $\begin{array}{l}\text { Divided society: } \\
\text { masters (workers, } \\
\text { peasants) and alien } \\
\text { classes - "non-masters" } \\
\text { (meschane, kulaks, the } \\
\text { clergy, bureaucrats, } \\
\text { parasites, wreckers and } \\
\text { saboteurs) }\end{array}$ & $\begin{array}{l}\text { United society/mili- } \\
\text { tary camp standing } \\
\text { against the secret } \\
\text { internal and external } \\
\text { enemies }\end{array}$ \\
\hline Personalization & Unfinished (leaders) & $\begin{array}{l}\text { Lenin + Bolshevik } \\
\text { leaders }\end{array}$ & $\begin{array}{l}\text { Stalin + Lenin + Bol- } \\
\text { shevik leaders }\end{array}$ \\
\hline Mythology & Unformed & Revolutionary myth & $\begin{array}{l}\text { Formation of the So- } \\
\text { viet mythological cy- } \\
\text { cle (myth of creation/ } \\
\text { revolutionary; myth of } \\
\text { the golden age (Com- } \\
\text { munism); heroic myth; } \\
\text { myth of transfigura- } \\
\text { tion; eschatological } \\
\text { myth) }\end{array}$ \\
\hline
\end{tabular}


Table 1. Continued

\begin{tabular}{|l|l|l|l|}
\hline $\begin{array}{l}\text { Rituals and } \\
\text { holidays }\end{array}$ & $\begin{array}{l}\text { Rituals associated } \\
\text { with service in the Red } \\
\text { Army (Oath of Alle- } \\
\text { giance); revolutionary } \\
\text { holidays }\end{array}$ & $\begin{array}{l}\text { Cult of Revolution, } \\
\text { revolutionary and state } \\
\text { holidays (Election Day; } \\
\text { Constitution Day; Red } \\
\text { Army Day, and so on) }\end{array}$ & $\begin{array}{l}\text { Ritualization of col- } \\
\text { lective social practices } \\
\text { (meetings, congresses, } \\
\text { etc.); youth initiation } \\
\text { rituals (Little } \\
\text { Octobrists, Pioneers, } \\
\text { Komsomol); holiday } \\
\text { calendar (revolution- } \\
\text { ary, state, profession- } \\
\text { al, family) }\end{array}$ \\
\hline $\begin{array}{l}\text { Sites of } \\
\text { memory }\end{array}$ & $\begin{array}{l}\text { Obliteration of tsar- } \\
\text { ist sites of memory } \\
\text { + creation of sites } \\
\text { of revolutionary } \\
\text { memory (memorials to } \\
\text { victims, revolutionary } \\
\text { toponymics) Soviet } \\
\text { decrees; Declaration of } \\
\text { Rights of the Working } \\
\text { and Exploited People; } \\
\text { Constitution of the } \\
\text { RSFSR of 1918 }\end{array}$ & $\begin{array}{l}\text { Creation of the memo- } \\
\text { rial space of the Revo- } \\
\text { lution, which included } \\
\text { building of the Mau- } \\
\text { soleum and opening } \\
\text { Lenin museums; 1924 }\end{array}$ & $\begin{array}{l}\text { Constitution of the } \\
\text { Soviet symbols; Social- } \\
\text { ist city (architecture, } \\
\text { monuments, palaces } \\
\text { of culture; parks of } \\
\text { culture and recreation, } \\
\text { museums, toponyms); } \\
\text { Soviet culture; com- } \\
\text { munal lifestyle; 1936 } \\
\text { Constitution }\end{array}$ \\
\hline
\end{tabular}

green globe crowned with a laurel wreath against the red flag as an emblem for the new Russia. Each leaf on the laurel would have symbolized one of the "allied republics". It can be concluded that Khelaev anticipated what the national coat of arms of the USSR would eventually look like ${ }^{4}$.

Early Soviet history was characterized not only by "re-coding" of February symbols but also the search for new ones. The choice of symbols was aimed at highlighting the contrast between the new regime and the monarchical past and the Provisional Government. La Marseillaise was replaced with the International; the tricoloured flag - with the red flag; the double-headed eagle - with the sickle and hammer. As for the state institutions, the Soviets and the Red Army embodied the new regime.

At the revolutionary stage, power was not personified: the political discourse of that period used only the notion of the "leaders". Letters from workers and peasants to the new government demonstrate that they did not associate power with specific figures. The cult of Vladimir Lenin as the leader of the Revolution and Soviet state had emerged only by $1922^{5}$.

4 For more detail, see: B.I. Kolonitsky, Simvoly vlasti $i$ borba za vlast: $k$ izucheniyu politicheskoy kultury Rossiyskoy revolutsii 1917 g., "Kulturologia" 2002, 4 (24), pp. 98-114.

5 N.V. Shalaeva, Personifikatsia obraza vlasti v sovetskoy politicheskoy kulture $1920 \mathrm{kh}$ gg, "Vlast" 2014, 2, pp. 179-183. 
Working people as the symbol of the new state were represented by three key figures: a worker, a peasant, and a Red Army soldier as the revolutionary classes whose interests the new regime served. The Red Army soldier was supposed to protect the achievements of workers and peasants and, being a part of the symbolism surrounding the image of power, this figure acquired archetypical meanings ${ }^{6}$. Representatives of other social groups were associated with the past and were considered "hostile". In general, the mythology of the new power was still evolving and in all likelihood was connected with the utopia - the idea of the future as the ultimate goal worth dying for.

Revolutionary songs played an important role in the propaganda of Soviet state power. Their mobilizing energy was brought to light by the events of 1917, when songs became an instrument of unity, identification, self-organization, and demonstration of social sentiments and social needs. La Marseillaise was an unofficial anthem of the 1917 Revolution as the Provisional Government claimed the heritage of the Great French Revolution. La Marseillaise was later replaced by the International, which, along with other revolutionary songs, established the traditions of the Soviet song culture.

Days of Freedom and Remembrance Day for Victims of the Revolution were celebrated since 1917. At the same time, the accompanying rituals appeared. Later, these rituals and celebrations were successfully adopted by the Soviet government. The Soviet model of revolutionary holidays prioritized such practices as mass meetings, parades, pageants, and theatrical performances, thus, combining the Russian military traditions, Orthodox church rituals, and traditions of the revolutionary underground (Fig. 2).

New sites of memory started to emerge during the 1917 Revolution, in particular, burial sites of revolutionary heroes. This practice was supported by the Soviet government: on 12 April 1918, a decree was adopted proposing to demolish the "ugliest" sculptures and replacing them with new ones; to decorate streets for celebrations with revolutionary symbols such as flags and banners; and to rename streets, replace signs and emblems with new ones that would reflect the ideas and sentiments of the revolutionary Russia ${ }^{7}$.

6 V. Bonnel, Representatsia zhenschiny $v$ rannikh sovetskikh plakatakh, in: Vizualnaya antropologia: rezhimy vidimosty pri sotsialisme, E.R. Yarskaya-Smirnova, P.V. Romanova (eds.), Moskva: OOO 'Variant', Centre for Social Policy and Gender Studies, 2009, p. 247.

7 Dekret o pamyatnikakh respubliki ot 12 aprelya 1918 g., in: Dekrety sovetskoy vlasti, vol. 15, vol. 2, 17 marta-10 ijulja, Moskva: Gosudarstvennoe izdatelstvo politicheskoy literatury, 1959, pp. 95-97. 


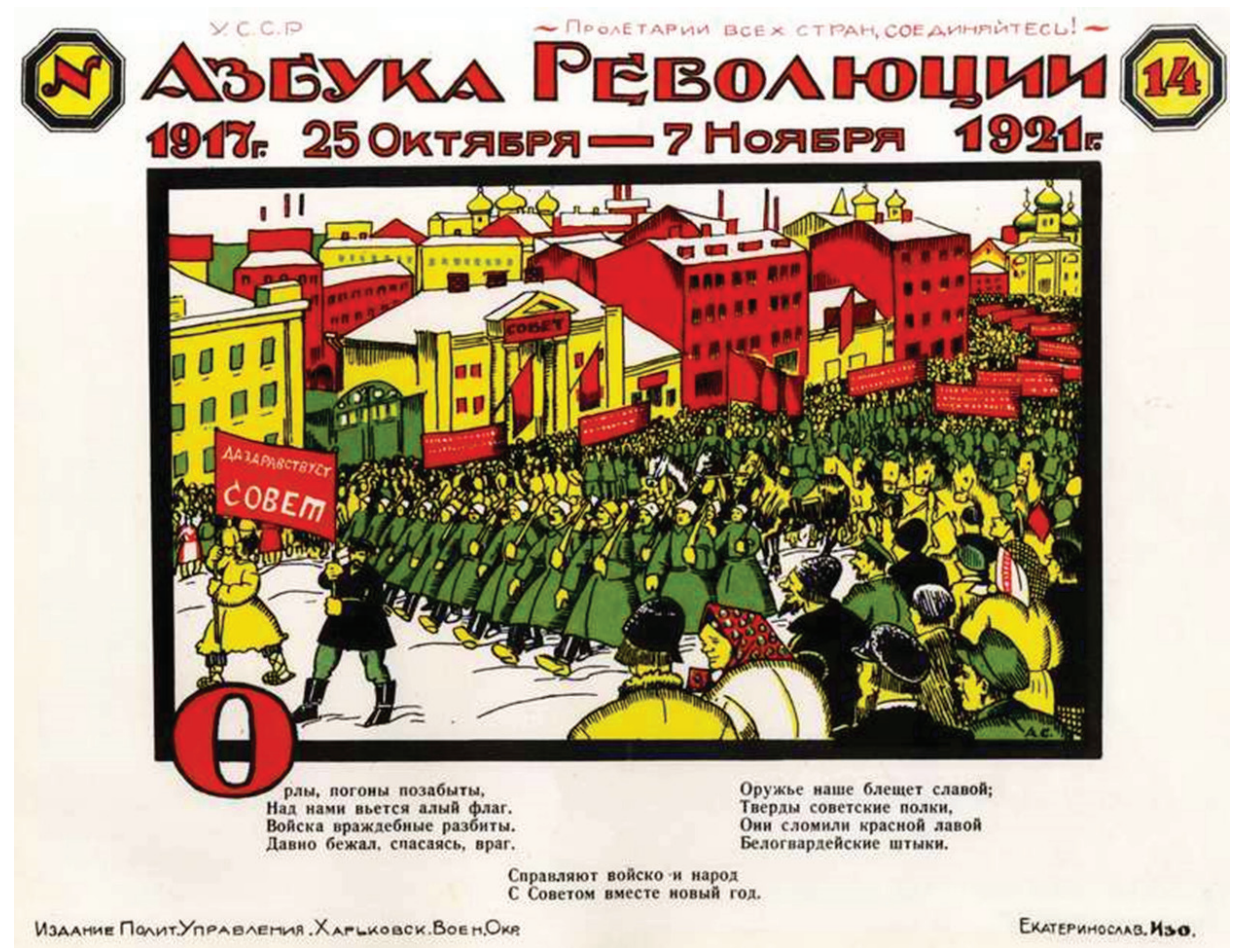

Fig. 2. Poster from the series ABC of the Revolution, Adolf Strakhov, 1921

At the early stage of its development, the Soviet ritual culture involved not only creation of the new mass festive culture and sites of memory but also new state ceremonies. One of the first rituals approved by the government was the Oath of Allegiance for Red Army soldiers, which started with the words: "I, a citizen of the Union of Soviet Socialist Republics, joining the ranks of the Workers and Peasants' Red Army, do hereby take the oath of allegiance $[\ldots]^{\prime \prime}$.

Another distinctive feature of the revolutionary image of power was the usage of new types of documents, including decrees of the Soviet government which formalized Soviet legislative practices throughout the revolutionary period and further on. Along with the legislative functions, decrees also served as communication media, as means of agitation and propaganda. Decrees formed a new legislative environment, state system, and social structure. Those decrees that described rules and regulations for execution of official documents are particularly interesting since they

8 Formula torzhestvennogo obeschania voinov Raboche-Krestyanskoy Krasnoy armii, in: Dekrety sovetskoy vlasti, p. 156. 


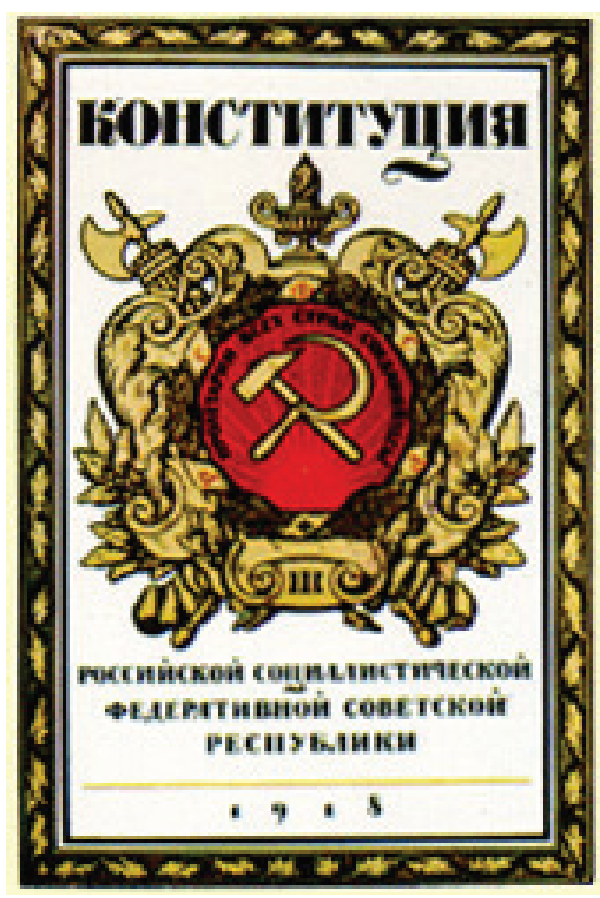

Fig. 3. The cover of the RSFSR Constitution of 1918

were perceived as an instrument of power and laid the foundation for the new bureaucratic system ${ }^{9}$. One of the most significant documents was the Declaration of Rights of the Working and Exploited People, adopted by the Third All-Russia Congress of the Soviets in January 1918 and later included into the first Soviet Constitution, adopted by the Fifth All-Russia Congress of the Soviets on 10 July 1918 (see Fig. 3) ${ }^{10}$.

By and large, at the revolutionary stage, the image of Soviet power, though incomplete and somewhat chaotic, was emotionally intense and based on the rigid dichotomy between friends and foes. This dichotomy symbolized the society split into two hostile camps: those defending the righteous cause of the Revolution and their enemies - the "good" and the "evil".

Workers and peasants' (people's) image of Soviet power evolved in the period between 1923 and 1929 in the conditions of NEP (New Economic

9 Postanovlenie o forme blankov gosudarstvennykh uchrezhdeny ot 2 marta 1918 goda, in: Dekrety sovetskoy vlasti, vol. 15, vol. 2, 25 oktyabrya 1917-16 marta 1918 g., Moskva: Gosudarstvennoe izdatelstvo politicheskoy literatury, 1957, pp. 514-515.

10 Konstitutsia (Osnovnoy Zakon) Rossiyskoy Sotsialisticheskoy Federativnoy Sovetskoy Respubliki, Prinyata V Vserossiyskim syezdom Sovetov v zasedanii ot 10 ijulja 1918 goda, http://www.hist.msu.ru/ER/Etext/cnst1918.htm\#1 [access: 6 II 2018]. 
Policy) and post-war reconstruction, and reflected the changing priorities of the Soviet government. When the Civil War was over, displays of power became less aggressive. Symbols of peaceful labour, international brotherhood, and expectations of the World Revolution started to prevail.

Power was now personified by Vladimir Lenin: by 1924, the iconography of Lenin as the chief leader (vozhd) with the accompanying mythologemes had been firmly established in the mass consciousness. Depending on the situation, the following variants of Lenin's iconography were used: Lenin as the leader of the world proletariat; the leader of the Bolshevik Party; a fervent revolutionary; a hero struggling for the liberation of the working class; a statesman; a man of genius; and "the most humane of all the humans".

The 1924 Constitution renewed the symbols of state power (flag and coat of arms), which reflected the vastness of the USSR state. These symbols included all the previous signs (sickle, hammer, star) but in a new colour scheme, in which the red and golden colours prevailed. The Soviets continued to exist as the symbol of statehood but they were no longer a classbased institution representing interests of the exploited people. Instead, they became an organ of people's power. The concept of "the people" was also expanded and acquired new meanings: the notion of classes was now augmented with the idea of diversity and unity, that is, the people were now presented as a unified multi-national community and masters of the country despite their social diversity and inequality (see Fig. 4).

In the second half of the 1920s, the revolutionary myth had already taken shape, with cinematography playing a pivotal role in this process. The trilogy of Sergey Eisenstein (Strike, 1924; Battleship "Potemkin", 1925; October, 1927) merits special attention in this respect as it created the image of the Revolution as a violent and uncontrollable civil riot but, even more importantly, turned the Revolution into a legend.

In the 1920s, the cult of the Revolution became a state cult and had a direct impact on the development of Soviet political culture and Soviet mythology. The Revolution was seen not only as the central event of the twentieth century but also as a universal concept, as a way for solving all kinds of problems - economic, social, political, technical, and moral. The word "revolution" was widely used in everyday speech. Moreover, it was used in construction of "revolutionary" names and toponyms, being second in popularity only to the name of Lenin. The concept of "revolution" also included religious meanings as it was associated with such concepts as "faith", "miracle" and "bright future". According to Kolonistky, belief in miracles was one of the key elements of mass political consciousness in the 


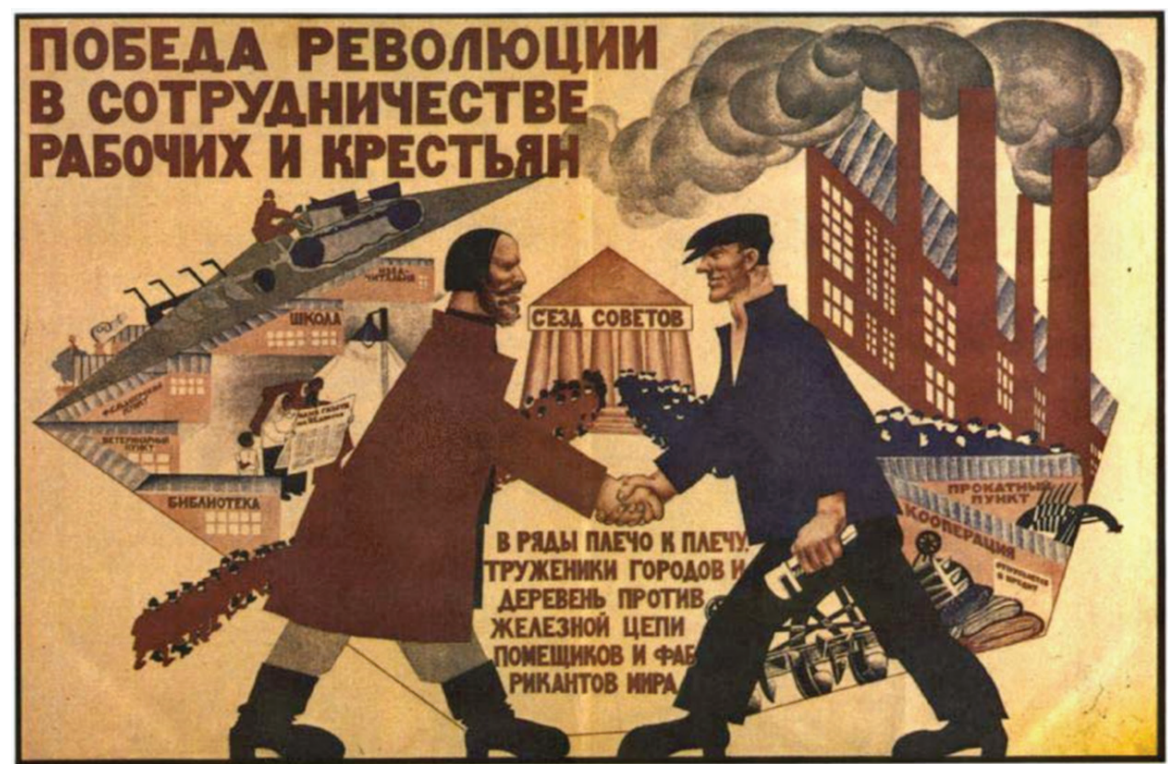

Fig. 4. Poster Victory of the Revolution lies in the cooperation of workers and peasants, M.M. Cheremnykh, 1925

revolutionary period ${ }^{11}$, since people at large retained the religious worldview. Religious meanings were thus re-coded into revolutionary symbols.

In the 1920s, the system of revolutionary holidays and celebrations gradually crystallized and took the place of religious ones. It should be noted that these festivities usually included mass theatrical performances, military and sports parades and mass meetings. The range of state ceremonies was enlarged through the inclusion of such events as elections of Soviet deputies, farewell ceremonies for recruits to the Red Army. These were seen not as a private occasion for people to exercise their civil rights but as a public duty. State holidays - Abolition of Monarchy, Commemoration of the Paris Commune, Anniversary of October Revolution, Anniversary of Lenin's Death, Day of the International - demonstrated people's loyalty to the government and the government's commitment to the interests of the people. Practices associated with the Party, Komsomol and the Pioneer Organization were ritualized, especially those related to the youth initiation and served to emphasize young people's role in the struggle for Communism.

11 B.I. Kolonistky, Navstrechu Oktyabryu, Krasnaya Paskha revolutsii, Nash Petrograd Chetverty Rim, "Delo", weekly newspaper, 23 IV 2007, http://www.idelo.ru/461/19.html [access: 6 II 2018]. 
The workers and peasants' (people's) image of Soviet power created in the 1920s signified a transition from the revolutionary image associated with the spontaneous protest and utopian ideas about the future to the image of powerful state, whose might relied on the "unity" of the people and the Communist Party and the "wisdom" of its leader. Ideas about people being the "masters" of their country receded into the past together with the NEP policy and the horizontal power model was replaced by the vertical hierarchy, which found reflection in the new symbols of power.

\section{PARTY-STATE IMAGE OF POWER. 1930s}

In the 1930s, displays of power were shaped by the cult of personality and, therefore, became explicitly personified: the cult of the dead leader was used to legitimize the cult of the living leader Joseph Stalin as "a loyal Party comrade", "true Communist" and "father of the peoples". This cult absorbed other symbols of power, including Soviet institutions, pushing to the foreground the idea of the Party as an intermediary responsible for delivering Lenin's ideas to the people and the leader as the messiah.

In the Stalinist epoch, the image of power was filled with signs of strength/might (machines, factories, power stations, tractors, planes, and so on); prosperity and happiness (bread, children, flowers), which were visualized by means of propaganda. Posters, films, sports and military parades, and theatrical performances created a festive and triumphant facade of Soviet reality, hiding the real problems the country was facing.

While in the 1920s Constructivist architecture flourished, in the 1930s it was partially replaced by the new, "wedding-cake" neo-classical style. In large cities, especially Moscow, palaces of culture and science, libraries, and museums were built. Recreation parks were laid out, decorated with alabaster sculptures of the youth, sportsmen, factory and kolkhoz workers, and marble sculptures of the leaders. Small towns and villages preserved their authentic look but were decorated with flags, banners, and posters. This space of Soviet style incorporated not only towns and villages but also invaded into the private space of individual people (their homes and domestic life), thus, forming one integral memory site, where all material objects and their designations (toponyms and language markers), people and relationships were embedded into the ideal picture of the future that had already come (present future) (Fig. 5).

In the new structure of the image, people are presented as united, not divided into opposing classes. This concept is based on the "tri-unity" of the working class, kolkhoz peasantry, and intelligentsia, that is, the unity 


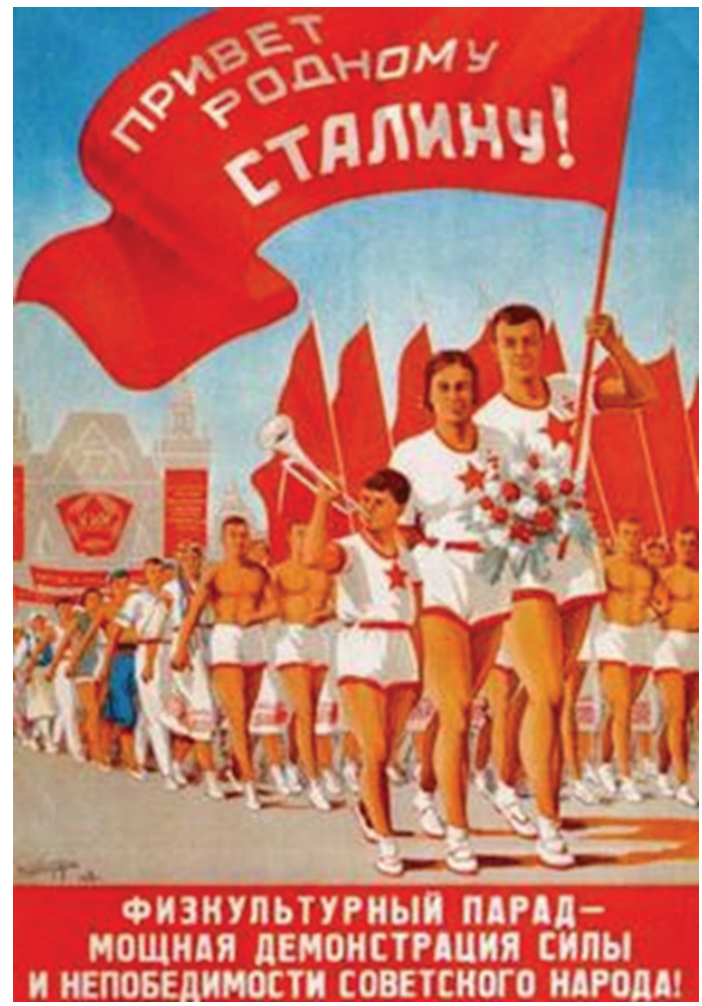

Fig. 5. Poster Sports parade vividly demonstrates the power and invincibility of the Soviet people, G. Kibaldin, 1938

is seen not only as class-related but also social and professional. The price that had to be paid for this unity was the constant struggle with the secret internal enemy and the fear that the Soviet state might be destroyed from the inside, which strengthened the repressive regime.

A specific symbol of that time was the 1936 Constitution, which declared socialist building and also lifted the restrictions on civil rights. The Constitution, which was adopted in the years of mass persecution, served as a cover-up for the totalitarian regime while constructing in the mass consciousness a parallel reality of the long-cherished dream coming true.

In the 1930s, the creation of Soviet mythology, explaining the past, present and future of the country, was almost complete. The full mythological cycle comprised the revolutionary (myth of creation), cosmogonic (myth about the historical inevitability of Communism), heroic and messianic myth, canonizing the trinity of leaders as the key figures in the historical process (Karl Marx, Vladimir Lenin, and Joseph Stalin) and the heroes of the revolution who sacrificed their lives to the revolutionary 
struggle (Vasily Chapaev, Nikolai Schors, Grigory Kotovsky and others). The cycle also included the myth of the golden age (society of the future). As for the eschatological concepts in the structure of the Soviet myth, they were mostly associated with the bourgeois world and the pre-revolutionary past $\mathrm{t}^{12}$.

To state revolutionary holidays there were added family (New Year, Mother's Day) and professional holidays (Red Army Day, Militia Day, and so on). Thus, a renewed holiday calendar was synchronized with natural cycles ${ }^{13}$.

As a result, by the late 1930s, the construction of the image of power was complete and was used as an instrument of internal (Soviet society) and external (other states) manipulation. Basic symbolic elements of power representation introduced by the February Revolution evolved into Party-state imagery in which the Revolution was replaced by an image of a strong state, the embodiment of revolutionary dreams and hopes. This image persisted through the generations and still evokes nostalgic reminiscences of the Soviet past.

\section{POSTERS OF THE EARLY SOVIET PERIOD AS A SOURCE AND MECHANISM OF FORMATION OF THE IMAGE OF POWER}

A special role in meeting the goals of social engineering was played by verbalization and visualization of the image of power, which induced emotional reactions and, thus, resonated with the public on the emotional and even subconscious level. The combination of visualization and verbalization is characteristic of media forms of mass art with the poster and "motion pictures", that is, cinematography, being the most effective in terms of impact.

In the early Soviet society, the main channel of propaganda was the poster - "street art, which was spread in millions and was meant for masses". As V. Polonsky put it, the poster was able to bring art closer to the people, catch their eye ${ }^{14}$. The political poster not only became an element of mundane life and accompanied Soviet people in public places (in the street, at work, in the shop, in administrative offices), but also penetrated into their

12 N.V. Shalaeva, Sovetsky gosudarstvenny prazdnik kak mekhanism formirovania representativnogo obraza vlasti $i$ sotsiokulturnoy kommunikatsii, "Vlast" 2013, 1, pp. 132-136.

${ }^{13}$ For more detail, see: L.N. Mazur, Konstruirovanie revolutsionnogo mifa v sovetskom khudozhestvennom kinematografe (1917-1953), “Vestnik arkhivista" 2017, 3, pp. 168-182.

14 S.N. Filimonchik, Prazdnichnaya kultura Petrozavodska v 1920-1930-e gg., "Carelica" 2015, 1 (15), pp. 38-45, http://carelica.petrsu.ru/2015/PHILIMONCHIK.pdf [access: 6 II 2018]. 
private space and transformed their daily lives through the sheer power of its images and words.

In fact, this is where the potential of poster art resided - in the combination of verbal and visual techniques. The conceptual core of a poster is created by its visual imagery, especially the colour, form and rhythm of the picture. In Soviet poster art, power was represented through the red colour (the colour range predominantly consisted of the red, white and black); the geometrical forms of the star and circle (eternity); and the marching rhythm. The symbolic inventory connected with the public image of state power was often linked to the signs of the past ("shackles/chains of the past"), future (star/sun), movement (train/plane), might and power (tank, plane, battleship), labour (sickle/hammer/factory/tractor), people (worker/peasant/soldier), and enemy (burzhuy/priest/White Army soldier/ meschanin).

Posters containing these elements evoked a strong emotional reaction, which was intensified through captions - short, concise, expressive, often rhyming. Not only did captions illustrate the visual imagery and explain it but they also "activated" people's second signal system and stimulated the transformation of emotion into motivation.

The Soviet poster constructed a specific worldview by establishing associations between the concepts of "good" and "evil" and certain images, signs and colours ${ }^{15}$. A special role in this process was played by symbolism of the colour red as the symbol of the Revolution and the blood sacrificed for Communism. A popular symbol associated with power in the early Soviet posters was the five-pointed star. Apart from being the symbol of the Red Army's valour, it acquired a new meaning of the guiding sign and was linked to the image of the sun (future) that shone on the world's proletariat and showed them the way to Communism.

The image of the guiding star, in an almost Biblical sense, is represented in the poster Nothing is getting in the way of the Red Army published in 1919 in Kharkov. The rhyming caption goes as follows: "The Red Army star is shining over the world/ Free and bright/ Its light shines on all the peoples/ The rays of its eternal red light/ as if seen through the fog/ guide workers of all countries, /who, like pilgrims of old days, are on their way to the $\operatorname{star}^{\prime \prime 16}$ (Fig. 6). The poetical rhythm connecting the key words of the Soviet image (world, freedom, light, Red Army, star, workers) gives the

15 V. Polonsky, Russky revolutsionny plakat, Moskva: Gosudarstvennoe izdatelstvo, 1924, p. 3.

16 N.V. Shalaeva, Sotsiokulturnye zadachi sovetskoy vlasti i politichesky plakat period Grazhdanskoy voyny, "Istoricheskie, filosofskie, politicheskie i yuridicheskie nauki, kulturologia i iskusstovedenie. Voprosy teorii i praktiki" 2012, 5 (19), in 2 volumes, vol. 1, pp. 209-214. 


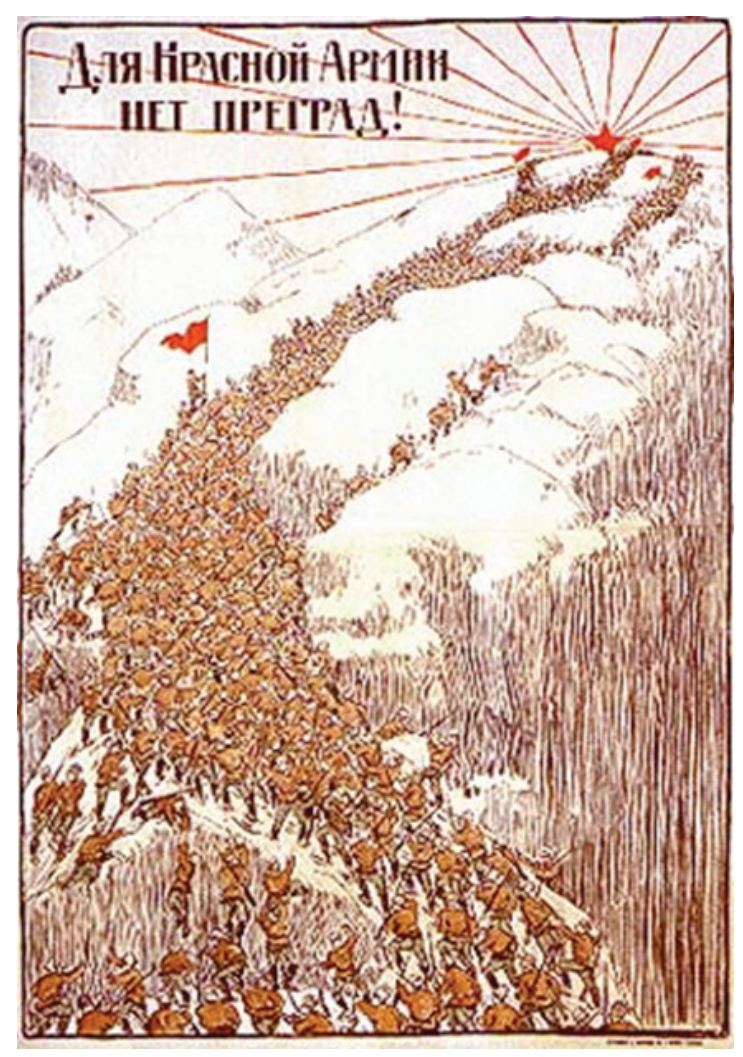

Fig. 6. Poster Nothing is getting in the way of the Red Army, 1919, unknown artist

text a chant-like quality, aimed not only at strengthening the readers' commitment but at "establishing" them in faith.

In the early Soviet period, the Soviet political poster represented two main themes: the struggle with the past and building of the new world. The idea of struggle was central to poster imagery, the only element that varied was the image of the enemy. Moreover, this struggle acquired sacral meanings and was seen as the only way to reach the bright Communist future. The concept of struggle was closely connected to the concept of war and stimulated people's willingness to make personal sacrifices and to be ruthless towards their enemies. Thus, the Soviet mode of mass consciousness and type of behaviour were formed ("staunch communist").

The early Soviet propaganda posters, especially those of the Revolution, Civil War and NEP periods, were populated by classes rather than individual characters, thus, reflecting the evolving structure of Soviet society. At the early stage, posters mostly depicted workers/proletarians and peasants, sometimes together, which illustrated the social basis of the Soviet state of the 
"proletariat's dictatorship". Together with the Red Army, these characters stood up for the "good cause", invariably defeating the "evil" - burzhui, the White Army, imperialism, religion, and other symbols of the past.

In the 1930s, the image of the people as the social base of the regime became more diverse and included not only social and class-related but also national and demographic (age and gender) types. The concept of "Soviet people" incorporated all these types. Propaganda posters of that time were dominated by the figure of Joseph Stalin, who had gradually replaced not only other leaders of the Revolution but also other symbols of Soviet power. The 1930s posters formed iconography of Stalin's image that reflected his omnipresence and variety of statuses: as people's leader showing them the right way (messiah); as the helmsman and head of the Party (wise leader); friend/brother/father/grand-father (person); thinker and prophet (man of genius).

Posters were not only means of propaganda, but were also used for agitation. The flexibility of this art made posters an indispensable instrument for manipulating public opinion in response to the changes in the government's agenda. In the years of the Revolution and Civil War, the poster helped the government recruit people into the Red Army and promote such measures as The Decree on Peace, The Decree on Land, The Decree on Workers' Control, and so on. The posters also formed the image of the enemy in the mass consciousness. In the 1920s, the poster started to perform a wider range of functions: along with practical tasks of stimulating economic revitalization and promotion of the new lifestyle, posters and films constructed the myth of the Revolution, popularizing its history, goals and aims among the illiterate and semi-literate population (Poster series $A B C$ of the Revolution by Adolf Strakhov, 1921. See Fig. 2). More complex propaganda tasks contributed to thematic and stylistic diversity of poster forms, which sought new artistic means to reflect the transformations of society and its transition to the future (Fig. 7).

The 1930s poster was drastically different from the previous versions: it focused on the success of industrialization and collectivization, on happy and prosperous life, and, in addition, the need for protection of the Socialist motherland from internal and external enemies. In this period, poster art was canonized and lost its former diversity: being subjected to the principles of "Socialist Realism", it became another channel of "Soviet style" (see Fig. 5). Posters of that time emphasize the strength and might of the state by employing images of the army, aviation, and machines. They also depict industrialization through the images of power stations and factories being built. It is remarkable that in the 1930s posters, the colours are softer and more varied and that lighter shades, especially of 


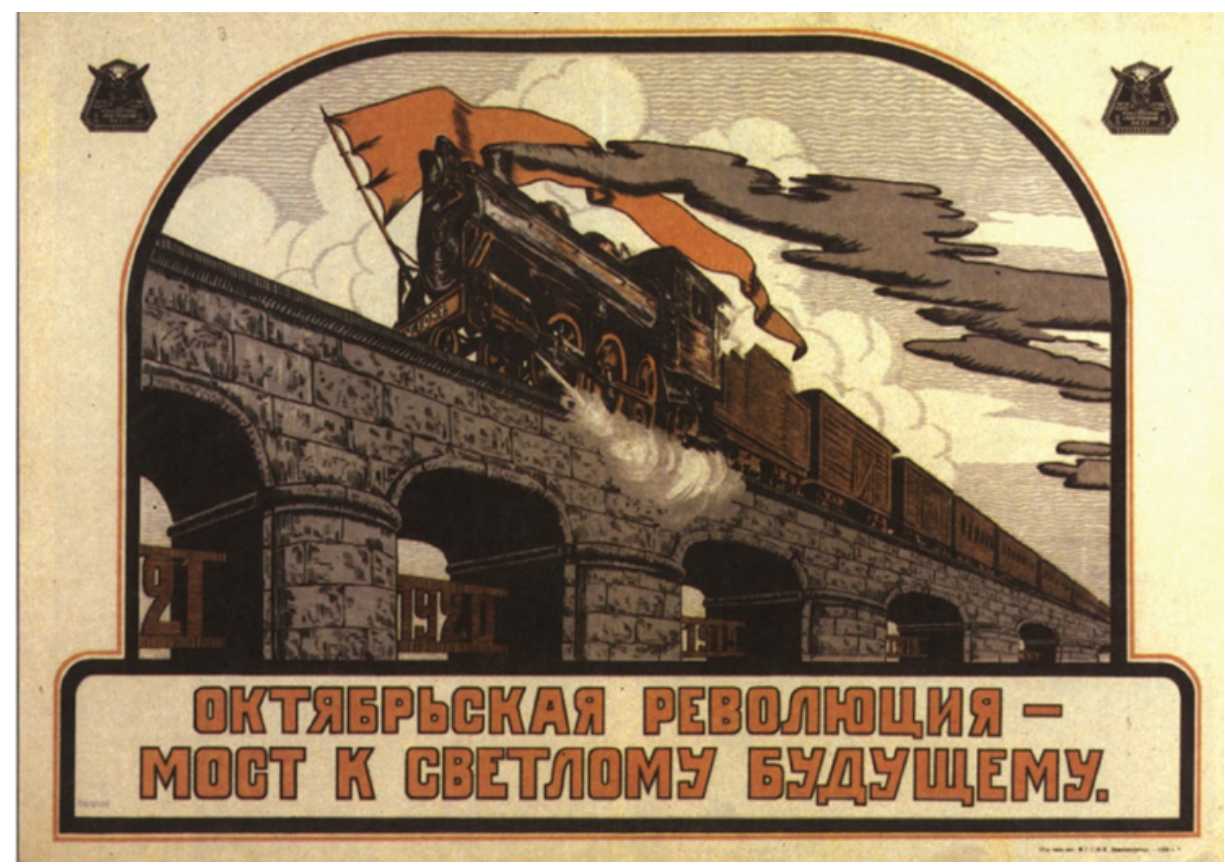

Fig. 7. Poster October Revolution is a bridge to the bright new future, 1927

the white, prevail. Poster art represented the society of the future as the dream that had already come true.

Thus, the information structure of the poster comprised short, catchy captions and visual imagery with colours and style (iconographic style resembling the traditional folk lubok) that appealed to the mass audience. By employing these means, the poster not only conveyed the new government's key ideas to the public but also helped create the necessary emotional effect, enhance people's motivation and mythologize the mass consciousness. Poster art established a special contact zone in which individual and mass consciousness merged to create the feeling of co-participation and to construct social identities of new classes and groups.

\section{CONCLUSION}

The image of power served as the main instrument to manipulate mass consciousness: it was used not only to intimidate people but also to foster their sense of loyalty and allegiance. Moreover, the public image of state power helped to distinguish the Soviet regime from its antecedents and contemporary alternatives. In its development, the image of 
power went through the following stages: construction, reconstruction, and deconstruction, which both reflected the evolution of the Soviet regime and met its needs. Each stage corresponded to its own official image of power: for example, the period from 1918 to 1923 (Revolution and Civil War), to the revolutionary image (construction). Though incomplete, this image was charged with emotion and was characterized by the rigid dichotomy between friends and foes. This dichotomy symbolized the society split into two opposing camps. This image was the most emotionally intense and the most influential as it was passed on to the following generations and was imprinted on their subconscious level. In Soviet history, there were at least two more periods when this image was revived in the collective historical memory: it was the "Thaw", which launched the process of de-Stalinization, and the perestroika. Both periods were characterized by democratization, which relied on the symbols of the Revolution.

The period between 1924 and 1929 (NEP) corresponded to the peasants and workers' (people's power) image of Soviet power, which was aimed at restoration and transformation of the society as a part of the Communist project. Ideologically, at the core of this new image of power was still the cult of the Revolution, which was reconstructed to meet the new targets of Socialist building. These targets were considered to be the logical continuation of the revolutionary processes. Due to a number of objective and subjective reasons, this image was not developed further and at later stages was partially dismantled because it did not meet the new needs of the government.

In the 1930s (Stalinist epoch), the deconstruction of the revolutionary image was followed by the creation of the Party-state image of power, which used the ideas of the Revolution but treated them as a part of the heroic past and a necessary step towards building the desired future - Socialist society as the first phase of Communist society. In the future, the only force that would guarantee that the achievements of the October Revolution would be preserved would be the Communist Party and its leader, Joseph Stalin. The Party-state image of Soviet power differed from the earlier variations because it used emotionally charged symbols of strength, unity and ruthlessness towards the enemies. Thus, this image was targeted at the "children of the Revolution", in particular young people, fostering nostalgia and securing public support of the regime ${ }^{17}$.

17 I.A. Esaulov, Kategoria sobornosti v russkoy literature, Petrozavodsk: Petrozavodsk University's Publishing House, 1995, p. 174; S. Sheshunova, Yazyk propagandy 1918-1922 $v$ kontekste russkoy kultury, http://postsymbolism.ru/joomla/index.php?id=33\&option=com_ content\&task=view [access: 6 II 2018]. 
Overall, throughout the early Soviet period, the public displays of Soviet power conveyed four key ideas: struggle, klassovost, unity, and future. The only thing that changed was the emphasis shifting from one of these elements to another. These elements set the main trend in the evolution of the image of power.

In the early Soviet period, this image was constructed primarily with the help of agitation and propaganda ("Agitprop"), with the key role played by the political poster art. It can be said that posters provided the main channel for visualization and verbalization of the image of power. As cinematography and television developed, the role of graphic visual propaganda such as the poster was diminishing although the concept of a political poster never lost its significance but instead was transformed into other forms of power legitimation and indoctrination.

\section{REFERENCES}

\section{Primary Sources}

Dekret o pamyatnikakh respubliki ot 12 aprelya 1918 g., in: Dekrety sovetskoy vlasti, vol. 15, vol. 2, 17 marta-10 ijulja, Moskva: Gosudarstvennoe izdatelstvo politicheskoy literatury, 1959.

Konstitutsia (Osnovnoy Zakon) Rossiyskoy Sotsialisticheskoy Federativnoy Sjvetskoy Respubliki, Prinyata V Vserossiyskim syezdom Sovetov v zasedanii ot 10 ijulja 1918 goda, http:// www.hist.msu.ru/ER/Etext/cnst1918.htm\#1

Postanovlenie o forme blankov gosudarstvennykh uchrezhdeny ot 2 marta 1918 goda, in: Dekrety sovetskoy vlasti, vol. 15, vol. 2, 25 oktyabrya 1917-16 marta 1918 g., Moskva: Gosudarstvennoe izdatelstvo politicheskoy literatury, 1957.

Formula torzhestvennogo obeschania voinov Raboche-Krestyanskoy Krasnoy armii, in: Dekrety sovetskoy vlasti, vol. 15, vol. 2, Moskva: Gosudarstvennoe izdatelstvo politicheskoy literatury, 1959.

\section{Secondary Literature}

Bonnel V., Representatsia zhenschiny $v$ rannikh sovetskikh plakatakh, in: Vizualnaya antropologia: rezhimy vidimosty pri sotsialisme, E.R. Yarskaya-Smirnova, P.V. Romanova (eds.), Moskva: OOO ‘Variant', Centre for Social Policy and Gender Studies, 2009.

Esaulov I.A., Kategoria sobornosti v russkoy literature, Petrozavodsk: Petrozavodsk University's Publishing House, 1995.

Filimonchik S.N., Prazdnichnaya kultura Petrozavodska v 1920-1930-e gg., "Carelica" 2015, 1 (15), http://carelica.petrsu.ru/2015/PHILIMONCHIK.pdf

Kolonitsky B.I., Simvoly vlasti i borba za vlast: $k$ izucheniyu politicheskoy kultury rossiyskoy revolutsii 1917 g., St. Petersburg 2000.

Kolonitsky B.I., Simvoly vlasti i borba za vlast: $k$ izucheniyu politicheskoy kultury Rossiyskoy revolutsii 1917 g., "Kulturologia" 2002, 4 (24).

Kolonistky B., Navstrechu Oktyabryu, Krasnaya Paskha revolutsii, Nash Petrograd - Chetverty Rim, “Delo”, weekly newspaper, 23 IV 2007, http://www.idelo.ru/461/19.html 
Mazur L.N., Konstruirovanie revolutsionnogo mifa v sovetskom khudozhestvennom kinematografe (1917-1953), “Vestnik arkhivista" 2017, 3.

Polonsky V., Russky revolutsionny plakat, Moskva: Gosudarstvennoe izdatelstvo, 1924.

Romanovich N.A., Obraz vlasti kak otrazhenie rossiyskoy politicheskoy kultury, "Vestnik VGU. Seria: lingvistika i mezhkulturnaya kommunikatsia" 2010, 1.

Shalaeva N.V., Personifikatsia obraza vlasti v sovetskoy politicheskoy kulture 1920kh gg, "Vlast" $2014,2$.

Shalaeva N.V., Sotsiokulturnye zadachi sovetskoy vlasti i politichesky plakat period Grazhdanskoy voyny, "Istoricheskie, filosofskie, politicheskie i yuridicheskie nauki, kulturologia i iskusstovedenie. Voprosy teorii i praktiki" 2012, 5 (19), in 2 volumes, vol. 1.

Shalaeva N.V., Sovetsky gosudarstvenny prazdnik kak mekhanism formirovania representativnogo obraza vlasti $i$ sotsiokulturnoy kommunikatsii, "Vlast" 2013, 1.

Sheshunova S., Yazyk propagandy 1918-1922 v kontekste russkoy kultury, http://postsymbolism.ru/joomla/index.php?id=33\&option=com_content\&task=view

Vortman R., Offitsialnaya narodnost' i natsionalny mif rossiyskoy monarkhii XIX veka, in: ROSSIA/RUSSIA, 3 (11): Kulturnye praktiki v ideologicheskoy perspective, Moskva 1999.

\section{STRESZCZENIE}

W artykule zanalizowano powstanie i rozwój oficjalnego obrazu radzieckiej władzy państwowej między rokiem 1917 a latami trzydziestymi. Obraz ten był konstruowany świadomie i zawierał symbole państwowości (godło, motto, flagę i hymn); instytucje, które symbolizowały cechy organizacji władzy; przywódców jako uosobienie władzy; mit państwa, rytuały; miejsca pamięci. We wczesnych latach istnienia państwa ewolucja obrazu władzy odzwierciedlała zmiany w samoświadomości rządu. Można wyodrębnić trzy sukcesywne wersje tego obrazu co do jego struktury i zawartości: wyobrażenie rewolucyjne, „ludowe” (robotniczo-chłopskie) i partyjno-państwowe. $\mathrm{W}$ artykule opisano strukturę tych wersji i czynniki kształtujące ich rozwój.

Słowa kluczowe: symbole władzy, rząd radziecki, społeczeństwo wczesnoradzieckie, obraz władzy radzieckiej

\section{NOTA O AUTORZE}

Ludmiła Nikołajewna Mazur - doktor nauk historycznych, pracownik naukowo-dydaktyczny Instytutu Nauk Humanistycznych i Sztuk Uralskiego Uniwersytetu Federalnego w Jekaterynburgu. W kręgu jej zainteresowań badawczych znajdują się: historia wsi w Rosji w drugiej połowie XIX i na początku XX w., metody badań historycznych, historia rodziny, masowe źródła historyczne i urbanistyka historyczna. Autorka monografii: Cesa и деревни Среднего Урала в ХХ веке. Статистико-этнографическое описание, Екатеринбург 2003; Эволюичия сельских поселений Среднего Урала в ХХ веке: опьт диналического анализа, Екатеринбург 2006; Российская деревня в условиях урбанизации: региональное измерение (вторая половина XIX-XX в.), Екатеринбург 2012, podręczników: Информационное обеспечение управления: современные тенденции развития, Екатеринбург 1999; Методь исторического исследования, Екатеринбург 2010 oraz ponad 260 prac naukowych. E-mail: lmaz@mail.ru

This research is supported by the grant of the Russian Science Foundation (project № 16-18-10106 “The Early Soviet Society as a Social Project: Concepts, Mechanisms of Realization, and Results"). 